\title{
Effects of Piperonyl Butoxide and Tetramethrin Combinations on Biological Activities of Selected Synthetic Pyrethroid Insecticides against Different Housefly (Musca domestica L., Diptera: Muscidae) Populations
}

\author{
G. CAKIR ${ }^{1}$, O. YAVUZ ${ }^{2}$, O. KOCAK \\ ${ }^{1}$ Department of Biology, Faculty of Science, Ankara University, Ankara, Turkey \\ ${ }^{2}$ Department of Pharmacology-Toxicology, Faculty of Veterinary Medicine, Ondokuz Mayis University, \\ Samsun, Turkey \\ ${ }^{3}$ Insecticide Test and Production Unit, Technology Application and Research Centre, Hacettepe University, \\ Ankara, Turkey
}

Received April 19, 2007

Accepted June 11, 2008

\begin{abstract}
Cakir G., O. Yavuz, O. Kocak: Effects of Piperonyl Butoxide and Tetramethrin Combinations on Biological Activities of Selected Synthetic Pyrethroid Insecticides against Different Housefly (Musca domestica L., Diptera: Muscidae) Populations. Acta Vet. Brno 2008, 77: 467-474.

Piperonyl butoxide (PBO), a methylenedioxyphenyl compound, is primarily used as a synergist in combination with space spray, residual and admixture products for the control of insect pests in or around domestic and commercial premises, especially food preparation areas. Also, tetramethrin is known as a knockdown agent on target organism and it is generally used with piperonyl butoxide. In this study, effects of piperonyl butoxide and tetramethrin combinations on biological activities of synthetic pyrethroids, cypermethrin, deltamethrin, and permethrin against different housefly (Musca domestica Linnaeus, 1758) populations were evaluated. In addition, the biological efficiency of the insecticides used in the study, insecticide + PBO and insecticide + $\mathrm{PBO}+$ tetramethrin combinations, against the WHO standard sensitive housefly population and housefly populations collected from different parts of Turkey were compared.

Results showed that PBO extensively promoted the ratio of knockdown and killing effect values of the insecticides. The results also indicated that $\mathrm{PBO}$ and $\mathrm{PBO}+$ tetramethrin combinations moderately reduced the knockdown effect times of all formulation in all housefly populations. The knockdown effect times were more decreased by insecticide $+\mathrm{PBO}+$ tetramethrin combinations than insecticides that are used alone and insecticide + PBO combinations.
\end{abstract}

Pest control, insect control, synergism, Turkey insects, fight against insect vectors of disease

Synthetic pyrethroid compounds were derived from long-term studies on the structural activity of pyrethrins extracted from the dried flower heads of the pyrethrum plant, Chrysanthemum cinerariaefolium. Recently, the pyrethroids have been found to be valuable pesticides with differing stability to light, low volatility, high insecticidal potency, and low toxicity to mammals under normal conditions of use (WHO 1985; Wickham 1998; Kaya and Bilgili 2002). But wide application and uncontrolled use of synthetic pyrethroids and other insecticides causes resistance in the target organisms (WHO 1986, 1988, 1992). Previous studies, carried out in a number of countries including Turkey, showed that house flies (Musca domestica Linnaeus, 1758) in houses and animal shelters can develop high resistance to organochlorines, organophosphates, carbamates, and synthetic pyrethroids (Tezok et al. 1973; Elyassaki 1986; WHO 1986, 1992; Caglar et al. 2000; Kasai and Scott 2000; Kristensen et al. 2000; Kočišová et al. 2002).

Several factors, e.g. the use of the same or related insecticide in large areas and over a long time, short life cycle of the insects, exposure of both larvae and adults to the same or related insecticide, promote the development of resistance to an insecticide (WHO 1986; Kocak 1998). One of the most important mechanisms of resistance to many classes of 
insecticides is enhanced detoxification mediated by cytochrome P450 monooxygenases. It is known that a major resistance factor in many species including house flies is the knockdown resistance $(k d r)$ gene or one of its alleles (Hodgson and Levi 1998; Kasai and Scott 2000).

However, application of different insecticides, restricted use of insecticides (using only when necessary) and residual sprays, avoiding the use same insecticides to control both larvae and adult flies, and using synergist and knockdown agent combinations can be carried out for preventing and reducing the development of resistance (WHO 1986).

Piperonyl butoxide (PBO), which is a methylenedioxyphenyl (MDP) compound, can inhibit cytochrome $\mathrm{P} 450$ monooxygenases. It is primarily used as a synergist in space spray, residual, and admixture products for the control of insect pests in or around domestic and commercial premises, especially food preparation areas (Farnham 1998; Wickham 1998; Pap et al. 2001). It has a synergistic action with the major classes of insecticides, such as pyrethrins, pyrethroids, carbamates, organophosphates, and many insect growth regulators (Keane 1998; Tomlin 1997).

The predominant position of PBO has been attributed to a variety of factors. It has high efficacy as a synergist with a wide range of insecticides, it has excellent stability during storage and in insecticide formulations, and it has a very wide range of uses on humans, animals, birds, and plants, as well as in food storage (Tozzi 1998; Wickham 1998).

Insecticides are usually expected to act very quickly in order to be considered efficacious by the consumers (Showyin 1998). For this reason, PBO is usually used in combination with some synthetic pyrethroids, such as bioallethrin, s-bioallethrin, and tetramethrin. These synthetic pyrethroids are known knockdown agents, and PBO + knockdown agent combination can provide strong knockdown and killing activity against target species (Showyin 1998; Wickham 1998).

In this study, the effects of the synergist PBO and knockdown agent, tetramethrin combinations, on biological efficiency of the synthetic pyrethroids cypermethrin, deltamethrin, and permethrin, against susceptible and various field housefly (Musca domestica L.) populations were evaluated. In addition, differences in efficiency of the insecticides used in the study, insecticide $+\mathrm{PBO}$ and insecticide $+\mathrm{PBO}+$ tetramethrin against WHO standard sensitive population and field populations collected from different parts of Turkey were investigated.

\section{Materials and Methods}

Test organism

WHO susceptible and four-field Musca domestica populations collected from main garbage dump and livestock farms in different cities of Turkey (Ankara, Istanbul, Izmir, and Adana) were used. Entomological determination of Musca domestica in the working areas was made by the identification key given for this species (Mallis 1969). These populations were reared at $27 \pm 1{ }^{\circ} \mathrm{C}$ and $65 \%$ relative humidity with a 12-h photoperiod in Hacettepe University Insecticide Test and Production Laboratory. A generation was completed in $17 \pm 2$ days, and adult house flies were used for bioassays in 4-6 days.

Chemicals

Technical grade insecticides, synergist, and knockdown agent such as cypermethrin (94\%, Changzhou, China), deltamethrin (96\%, Changzhou, China), permethrin (96\%, Changzhou, China), PBO (92\%, Endura, Italy), and tetramethrin (93\%, Changzhou, China), were used. All insecticides, synergist, and knockdown agent were diluted in analytical grade acetone (Merck, Germany). House flies were made unconscious with $\mathrm{CO}_{2}$ (HABAS, Turkey).

Experimental design

The study was carried on three insecticide groups. Application doses were determined according to WHO recommendations (Chavasse and Yap 1997). The insecticides used, combination ratios, and application doses of insecticides, synergist, and knockdown agent are shown in Table 1.

Bioassays

Biological efficiency tests were performed according to the WHO standard residual surface methods with some deviations (Busvine 1971; WHO 1981a,b). Briefly, $200 \mathrm{ml}$ glass jars, whose insecticidal field is $140 \mathrm{~cm}^{2}$, were 
Table 1. Used insecticide groups, combination ratios and application doses of insecticides, synergist, and knockdown agent

\begin{tabular}{|c|c|c|}
\hline $\begin{array}{c}\text { Group I } \\
\text { (Dose: mg.a.i. } / \mathrm{m}^{2} \text { ) }\end{array}$ & $\begin{array}{c}\text { Group II } \\
\left.\text { (Dose: mg.a.i. } / \mathrm{m}^{2}\right)\end{array}$ & $\begin{array}{c}\text { Group III } \\
(\text { Dose: mg.a.i./m²) }\end{array}$ \\
\hline $\begin{array}{l}\text { Cypermethrin } \\
\left(70 \mathrm{mg} / \mathrm{m}^{2}\right)\end{array}$ & $\begin{array}{l}\text { Cypermethrin }+ \text { PBO }(1+1) \\
\left(70+70 \mathrm{mg} / \mathrm{m}^{2}\right)\end{array}$ & $\begin{array}{c}\text { Cypermethrin }+ \text { PBO }+ \text { Tetramethrin } \\
(1+1+1) \\
\left(70+70+70 \mathrm{mg} / \mathrm{m}^{2}\right)\end{array}$ \\
\hline $\begin{array}{l}\text { Deltamethrin } \\
\left(15 \mathrm{mg} / \mathrm{m}^{2}\right)\end{array}$ & $\begin{array}{l}\text { Deltamethrin + PBO }(1+1) \\
\left(15+15 \mathrm{mg} / \mathrm{m}^{2}\right)\end{array}$ & $\begin{array}{c}\text { Deltamethrin + PBO + Tetramethrin } \\
(1+1+1) \\
\left(15+15+15 \mathrm{mg} / \mathrm{m}^{2}\right)\end{array}$ \\
\hline $\begin{array}{l}\text { Permethrin } \\
\left(62.5 \mathrm{mg} / \mathrm{m}^{2}\right)\end{array}$ & $\begin{array}{l}\text { Permethrin + PBO }(1+1) \\
\left(62.5+62.5 \mathrm{mg} / \mathrm{m}^{2}\right)\end{array}$ & $\begin{array}{c}\text { Permethrin + PBO + Tetramethrin } \\
(1+1+1) \\
\left(62.5+62.5+62.5 \mathrm{mg} / \mathrm{m}^{2}\right)\end{array}$ \\
\hline
\end{tabular}

(a.i.: active ingredient)

used for application surface. Insecticide combinations ( $1 \mathrm{ml}$ in acetone) were pipetted into the glass jar, and the jars were rolled with a rotator until evaporation of acetone. These preparations were made $24 \mathrm{~h}$ before the test. Test room conditions were $24{ }^{\circ} \mathrm{C}$ and $65 \%$ relative humidity.

Doses, which were determined according to WHO recommendations (Chavasse and Yap 1997), were $70 \mathrm{mg}$ active ingredient (a.i.) $/ \mathrm{m}^{2}$ for cypermethrin, $15 \mathrm{mg}$ a.i. $/ \mathrm{m}^{2}$ for deltamethrin, and $62.5 \mathrm{mg}$ a.i. $/ \mathrm{m}^{2}$ for permethrin. $\mathrm{PBO}$ and tetramethrin doses were the same with their combined insecticides (Table 1).

House flies were made unconscious with $\mathrm{CO}_{2}$, and they were placed in the insecticide-treated jars. The mouths of the jars were covered with cloth and the number of knocked-down house flies was recorded at intervals of 0 , 5,10 , and $15 \mathrm{~min}$. After the test, the house flies were put in labelled clear jars. Moist cotton was placed on top of each jar, and the mortality percentage values were determined after $24 \mathrm{~h}$ from treatment with insecticides.

Data evaluation

$\mathrm{LT}_{50}$ (time to $50 \%$ knockdown for a fixed dose) values were defined with probit analysis as proposed by Finney (1977). Afterwards, R/S (knockdown resistance coefficient) values of field populations were calculated with the formula shown below. The R/S value of WHO susceptible population was accepted 1.00.

$\mathrm{R} / \mathrm{S}=\frac{\text { LT50 value of field population }}{\text { LT50 of WHO susceptible population }}$

Chi-square test was used for significance control of difference in mean knockdown effect percentage and mortality percentage values between insecticides and populations (Yalcin 1975; Ozdamar 1999). Variance analysis was used for statistical comparisons between populations and insecticides for $\mathrm{LT}_{50}$ and $\mathrm{LT}_{100}$ (time to $100 \%$ knockdown for a fixed dose) values. The significance controls among the populations and insecticides were performed with Duncan test (Duncan 1955).

\section{Results}

The mortality and knockdown effect percentage values of cypermethrin, deltamethrin, and permethrin formulations against housefly populations are shown in Tables 2, 3, and 4.

Statistical significance in the mean knockdown effect percentage for cypermethrin formulations was determined only in the Adana population $(p<0.01)$. Cypermethrin was very effective against other populations and significant difference occurred by PBO in the Adana population $(p<0.01)$. Significance in the mean mortality percentage for cypermethrin formulations was determined in Istanbul, Izmir, and Adana populations, and the difference was due to PBO in these populations $(p<0.01)$.

Biological activity of deltamethrin formulations was increased by PBO. Knockdown effect and mortality percentages of deltamethrin formulations were $100 \%$ with addition of PBO. The increasing knockdown effect proved significant in all field populations $(p<0.01)$ and the increasing mortality effect was significant in Izmir and Adana populations $(p<0.01)$.

Permethrin was moderately effective against all the populations. The knockdown effect 
Table 2. The mortality and knockdown effect percentage values of cypermethrin formulations against house fly populations

\begin{tabular}{|c|c|c|c|c|c|c|c|c|}
\hline \multirow[t]{2}{*}{$\begin{array}{l}\text { Biological } \\
\text { efficiency }\end{array}$} & \multirow[t]{2}{*}{ Population } & \multicolumn{2}{|c|}{ Cypermethrin } & \multicolumn{2}{|c|}{$\begin{array}{l}\text { Cypermethrin } \\
\quad+\mathrm{PBO}\end{array}$} & \multicolumn{2}{|c|}{$\begin{array}{l}\text { Cypermethrin } \\
\quad+\text { PBO } \\
+ \text { Tetramethrin }\end{array}$} & \multirow[t]{2}{*}{$\mathrm{X}^{2}$} \\
\hline & & $\mathrm{n}$ & $\%$ & $\mathrm{n}$ & $\%$ & $\mathrm{n}$ & $\%$ & \\
\hline \multirow[t]{5}{*}{$\mathrm{KD} \%{ }^{\mathrm{a}}$} & $\mathrm{WHO}^{\mathrm{c}}$ & 88 & 100 & 101 & 100 & 97 & 100 & - \\
\hline & Ankara & 98 & 100 & 107 & 100 & 86 & 100 & - \\
\hline & Istanbul & 71 & 100 & 82 & 100 & 104 & 100 & - \\
\hline & Izmir & 70 & 98.6 & 87 & 100 & 72 & 100 & 2.281 \\
\hline & Adana & 96 & 81.2 & 100 & 100 & 83 & 100 & $36.679 *$ \\
\hline \multirow[t]{5}{*}{$\mathrm{dx} \%{ }^{\mathrm{b}}$} & $\mathrm{WHO}^{\mathrm{c}}$ & 88 & 100 & 101 & 100 & 97 & 100 & - \\
\hline & Ankara & 98 & 97.9 & 107 & 100 & 86 & 100 & 3.966 \\
\hline & Istanbul & 71 & 90.1 & 82 & 100 & 104 & 100 & $18.851^{*}$ \\
\hline & Izmir & 70 & 81.4 & 87 & 100 & 72 & 100 & $31.306^{*}$ \\
\hline & Adana & 96 & 87.5 & 100 & 100 & 83 & 100 & $23.903 *$ \\
\hline
\end{tabular}

${ }^{*} p<0.01$

${ }^{\mathrm{a}} \mathrm{KD} \%$ : Knockdown effect percentage, ${ }^{\mathrm{b}} \mathrm{dx} \%$ : Mortality percentage, ${ }^{\mathrm{c}}$ Standard susceptible population

Table 3. The mortality and knockdown effect percentage values of deltamethrin formulations against house fly populations

\begin{tabular}{|c|c|c|c|c|c|c|c|c|}
\hline \multirow[t]{2}{*}{$\begin{array}{l}\text { Biological } \\
\text { efficiency }\end{array}$} & \multirow[t]{2}{*}{ Population } & \multicolumn{2}{|c|}{ Deltamethrin } & \multicolumn{2}{|c|}{$\begin{array}{l}\text { Deltamethrin } \\
\quad+\mathrm{PBO}\end{array}$} & \multicolumn{2}{|c|}{$\begin{array}{l}\text { Deltamethrin } \\
+ \text { PBO } \\
+ \text { Tetramethrin }\end{array}$} & \multirow[t]{2}{*}{$X^{2}$} \\
\hline & & $\mathrm{n}$ & $\%$ & $\mathrm{n}$ & $\%$ & $n$ & $\%$ & \\
\hline \multirow[t]{5}{*}{$\mathrm{KD}^{0} \%^{\mathrm{a}}$} & $\mathrm{WHO}^{\mathrm{c}}$ & 60 & 100 & 52 & 100 & 92 & 100 & - \\
\hline & Ankara & 76 & 92 & 94 & 100 & 71 & 100 & $13.359 *$ \\
\hline & Istanbul & 87 & 10.3 & 68 & 100 & 98 & 100 & $215.162 *$ \\
\hline & Izmir & 64 & 12.5 & 61 & 100 & 72 & 100 & $162.595 *$ \\
\hline & Adana & 78 & 38.5 & 118 & 100 & 93 & 100 & $155.708 *$ \\
\hline \multirow[t]{5}{*}{$\mathrm{dx} \%{ }^{\mathrm{b}}$} & $\mathrm{WHO}^{\mathrm{c}}$ & 60 & 100 & 52 & 100 & 92 & 100 & - \\
\hline & Ankara & 76 & 97.4 & 94 & 100 & 71 & 100 & 4.378 \\
\hline & Istanbul & 87 & 97.7 & 68 & 100 & 98 & 100 & 3.846 \\
\hline & Izmir & 64 & 65.6 & 61 & 100 & 72 & 100 & $51.466^{*}$ \\
\hline & Adana & 78 & 69.2 & 118 & 100 & 93 & 100 & $70.803^{*}$ \\
\hline
\end{tabular}

$* p<0.01$

${ }^{\mathrm{a}} \mathrm{KD} \%$ : Knockdown effect percentage, ${ }^{\mathrm{b}} \mathrm{dx} \%$ : Mortality percentage, ${ }^{\mathrm{c}}$ Standard susceptible population

and mortality percentage values of permethrin increased and were determined significant in Izmir and Adana populations $(p<0.01)$.

The findings showed that PBO increased the biological effects of all the insecticides. The knockdown effect and the mortality percentages of the insecticides were determined to be $100 \%$ with addition of PBO. Due to the strong synergistic effect of PBO, the additive effect of tetramethrin on the knockdown effect and mortality of insecticides could be not identified.

Comparison of mean $\mathrm{LT}_{50}$ and $\mathrm{LT}_{100}$ values between formulation groups used in the study is shown in Table 5. PBO and PBO + tetramethrin combinations extensively reduced the knockdown effect of all formulation against all the populations. Furthermore, a decrease of the $\mathrm{LT}_{50}$ and $\mathrm{LT}_{100}$ values was seen in insecticide + PBO + tetramethrin combinations compared to insecticides used alone and insecticide + PBO combinations. This finding determined the significance for $\mathrm{LT}_{100}$ values $(p<0.01)$. 
Table 4. The mortality and knockdown effect percentage values of permethrin formulations against house fly populations

\begin{tabular}{|l|c|c|c|c|c|c|c|c|}
\hline \multirow{3}{*}{$\begin{array}{l}\text { Biological } \\
\text { efficiency }\end{array}$} & \multirow{2}{*}{ Population } & \multicolumn{2}{|c|}{ Permethrin } & \multicolumn{2}{c|}{$\begin{array}{c}\text { Permethrin } \\
+ \text { PBO }\end{array}$} & \multicolumn{2}{c|}{$\begin{array}{c}\text { Permethrin } \\
+ \text { PBO } \\
+ \text { Tetramethrin }\end{array}$} & \multirow{2}{*}{$\mathrm{X}^{2}$} \\
\cline { 3 - 9 } & & $\mathrm{n}$ & $\%$ & $\mathrm{~N}$ & $\%$ & $\mathrm{n}$ & $\%$ & \\
\hline \multirow{5}{*}{$\mathrm{KD}^{2}{ }^{\mathrm{a}}$} & $\mathrm{WHO}^{\mathrm{c}}$ & 76 & 100 & 93 & 100 & 99 & 100 & - \\
\cline { 2 - 10 } & Ankara & 98 & 100 & 86 & 100 & 116 & 100 & - \\
\cline { 2 - 9 } & Istanbul & 56 & 100 & 98 & 100 & 83 & 100 & - \\
\cline { 2 - 9 } & Izmir & 65 & 56.9 & 71 & 100 & 80 & 100 & $74.734^{*}$ \\
\cline { 2 - 9 } & Adana & 82 & 80.5 & 78 & 100 & 64 & 100 & $29.839^{*}$ \\
\hline \multirow{3}{*}{$\mathrm{dx} \%{ }^{\mathrm{b}}$} & WHO & 76 & 100 & 93 & 100 & 99 & 100 & - \\
\cline { 2 - 9 } & Ankara & 98 & 100 & 86 & 100 & 116 & 100 & - \\
\cline { 2 - 9 } & Istanbul & 56 & 100 & 98 & 100 & 83 & 100 & - \\
\cline { 2 - 9 } & Izmir & 65 & 52.3 & 71 & 100 & 80 & 100 & $84.083^{*}$ \\
\cline { 2 - 9 } & Adana & 82 & 89 & 78 & 100 & 64 & 100 & $16.238^{*}$ \\
\hline
\end{tabular}

$* p<0.01$

${ }^{\mathrm{a}} \mathrm{KD} \%$ : Knockdown effect percentage, ${ }^{\mathrm{b}} \mathrm{dx} \%$ : Mortality percentage, ${ }^{\mathrm{c}}$ Standard susceptible population

Table 5. Statistical comparison of $\mathrm{LT}_{50}$ and $\mathrm{LT}_{100}$ values between Finally, the knockdown formulation groups used in the study (mean \pm SEM) resistance coefficient $(\mathrm{R} / \mathrm{S})$

\begin{tabular}{|l|c|c|}
\hline Formulation Group* & $\begin{array}{c}\mathrm{LT}_{50} \\
\mathrm{x} \pm \mathrm{Sx}\end{array}$ & $\begin{array}{c}\mathrm{LT}_{100} \\
\mathrm{x} \pm \mathrm{Sx}\end{array}$ \\
\hline Group I & $8.567 \pm 0.568^{\mathrm{a}}$ & $12.000 \pm 0.497^{\mathrm{a}}$ \\
\hline Group II & $3.767 \pm 0.568^{\mathrm{b}}$ & $7.100 \pm 0.497^{\mathrm{b}}$ \\
\hline Group III & $2.333 \pm 0.568^{\mathrm{b}}$ & $4.433 \pm 0.497^{\mathrm{c}}$ \\
\hline
\end{tabular}
values are shown in Table 6. Almost all populations that were used in this study began to develop resistance against the insecticides used. These findings showed that a,b,c Means with different superscript in the same column differ resistance developed in all
significantly $(p<0.01)$.

the populations, particularly

Cypermethrin + PBO, Deltamethrin + PBO, Permethrin + PBO; Group against permethrin.

III: Cypermethrin + $\mathrm{PBO}+$ Tetramethrin, Deltamethrin + $\mathrm{PBO}+$

Tetramethrin, Permethrin + PBO + Tetramethrin.

Table 6. Knockdown resistance coefficient (R/S) values of the insecticide formulations used in the study against house fly populations

\begin{tabular}{|l|c|c|c|c|c|}
\hline \multicolumn{1}{|c|}{ Insecticide } & WHO $^{*}$ & Ankara & Istanbul & Izmir & Adana \\
\hline Cypermethrin & 1.0 & 2.28 & 2.28 & 2.14 & 2.57 \\
\hline Cypermethrin + PBO & 1.0 & 1.25 & 1.25 & 1.00 & 1.5 \\
\hline Cypermethrin + PBO + Tetramethrin & 1.0 & 1.0 & 1.25 & 1.25 & 1.25 \\
\hline Deltamethrin & 1.0 & 1.0 & 2.5 & 2.5 & 2.5 \\
\hline Deltamethrin + PBO & 1.0 & 2.0 & 3.5 & 3.5 & 1.5 \\
\hline Deltamethrin + PBO + Tetramethrin & 1.0 & 1.5 & 1.0 & 1.75 & 1.0 \\
\hline Permethrin & 1.0 & 4.0 & 5.33 & 8.0 & 8.0 \\
\hline Permethrin + PBO & 1.0 & 3.33 & 3.33 & 4.66 & 2.0 \\
\hline Permethrin + PBO + Tetramethrin & 1.0 & 1.33 & 1.33 & 2.33 & 1.33 \\
\hline
\end{tabular}

*Standard sensitive population.

\section{Discussion}

PBO is a popular insecticide synergist, which uses rebound biological activity of synthetic pyrethroids and other insecticides against target species. Tetramethrin is normally used in 
combination with synergists and other insecticides for the control of flies, cockroaches, mosquitoes, wasps, and other insect pests in public health, animal shelters, and garden (Tomlin 1997; Farnham 1998; Showyin 1998; Stewart 1998; WHO 1990). In this study, effects of PBO and PBO + tetramethrin combinations on the biological effects of insecticides against house flies were investigated.

Knockdown and death effects of all the three insecticides used in this study moderately increased with the addition of PBO. This increase in values was determined in almost all populations, and it was found to be significant in some insecticides. These findings are similar to several other studies (Farnham 1998; Stewart 1998; Wickham 1998; Kasai and Scott 2000; Pap et. al. 2001). In this study, because knockdown and death effects of deltamethrin were lower than those of the other two insecticides, the synergistic effect of PBO was determined to be more prominent in deltamethrin. DeltamethrinPBO synergism was investigated and found to be significant for particular knockdown effect percentage values. These findings showed the importance of $\mathrm{PBO}$ for increasing the biological activity of synthetic pyrethroids (Hodgson and Levi 1998; Wickham 1998; Pap et. al. 2001).

Due to the strong synergistic effect of $\mathrm{PBO}$, knockdown and death effect of all insecticides against all populations were $100 \%$. Because of this, the effect of tetramethrin could not be determined. The beneficial effect of tetramethrin could be seen only in the knockdown effect times.

$\mathrm{LT}_{50}$ and $\mathrm{LT}_{100}$ values moderately decreased with $\mathrm{PBO}$, and this effect was seen stronger with the $\mathrm{PBO}+$ tetramethrin combination. These findings showed that a fast knockdown effect occurred with PBO, but PBO and tetramethrin should be used together for an immediate effect, which is desired by most consumers (Showyin 1998).

The resistance coefficient $(\mathrm{R} / \mathrm{S})$ values of the insecticide formulations showed that almost all the housefly populations used in the study began to develop resistance against cypermethrin, permethrin, and deltamethrin. But the resistance was not yet developed to a great extent. The R/S value of permethrin was found to be the highest value of all the insecticides.

For years, the drawback of vector control applications is the development of resistance to insecticides. In 1946, WHO reported that only two vector species were resistant to some insecticides. These counts increased dramatically to 150 and 198 vector species in 1980 and 1990, respectively (WHO 1992). In addition, several studies, such as Elyassaki (1986), Kasai and Scott (2000), Kristensen et al. (2000), and Kočišová et al. (2002), reported that house flies have started developing resistance against synthetic pyrethroids, as well as various other insecticide groups recently. The same results were found in studies conducted in Turkey (Tezok et. al. 1973; Caglar et. al. 2000).

Addition of PBO decreased R/S values and the PBO + tetramethrin combination decreased these values further. These findings showed the role of $\mathrm{PBO}$ and $\mathrm{PBO}+$ tetramethrin combinations in reducing resistance against synthetic pyrethroid insecticides (Showyin 1998; Wickham 1998).

This study indicated that the addition of PBO was very beneficial for the biological efficacy of synthetic pyrethroid insecticides. Furthermore, using tetramethrin which decreased the knockdown effect time and PBO together was evaluated as an important factor for consumer desire, particularly for the control of household vectors. In addition, the study showed that $\mathrm{PBO}$ and tetramethrin may reduce resistance of housefly populations against synthetic pyrethroids.

Finally, we conclude that the use of PBO and tetramethrin with synthetic pyrethroid insecticides provides the best results for the control of house flies, and $\mathrm{PBO}$ and tetramethrin at small doses are also effective in the control of vectors. This practice would be very beneficial for human, animal, and environmental health. 


\section{Účinek kombinace piperonyl butoxidu a tetrametrinu na biologické aktivity některých syntetických pyretroidních insekticidů proti různým populacím mouchy domácí (Musca domestica L., Diptera: Muscidae)}

Piperonyl butoxid (PBO), směs methylendioxyfenylu, se primárně používá synergicky $\mathrm{v}$ kombinaci se sprejovými, reziduálními a př́sadovými insekticidy sloužícími ke kontrole hmyzích škủdců v domácnostech, jejich okolí a v komerčních prostorách, zejména $\mathrm{v}$ místech zpracování potravin. Tetrametrin je znám jako omračovací agens a je všeobecně používán v kombinaci s piperonyl butoxidem. V této studii byl testován účinek kombinace piperonyl butoxidu a tetrametrinu na biologické aktivity syntetických pyretroid̊̊, cypermetrinu, deltametrinu a permetrinu proti různým populacím mouchy domácí (Musca domestica, Linnaeus, 1758). Navíc byl vyhodnocován biologický účinek insekticidů využitých v této studii, insekticid a PBO, insekticid spolu s PBO a tetrametrin na WHO standardní populaci mouchy domácí ve srovnání s populacemi much z různých částí Turecka. Výsledky ukázaly, že PBO velmi výrazně zvýšil počet insekticidy omráčených a zabitých much. Výsledky také ukazují, že PBO a PBO spolu s tetrametrinem mírně redukovaly čas potřebný k omráčení mouchy u všech insekticidů a všech muších populací. Čas potřebný k omráčení byl kratší v př́padě kombinace insekticid spolu s PBO a tetrametrinem než $\mathrm{v}$ př́padě, kdy byl použit pouze insekticid, nebo insekticid v kombinaci s PBO.

\section{References}

BUSVINE JR 1971: A Critical Review of the Techniques for Testing Insecticides. $2^{\text {nd }}$ ed. England, pp. 1-345

CAGLAR SS, AKINER M, YAZGAN N 2000: Resistance to organochlorine and pyrethroid insecticides in different populations of $M$. domestica L. (Diptera: Muscidae). Paper presented at $13^{\text {th }}$ European Society for Vector Ecology Meeting, 24 - 29 September, Antalya, Turkey

CHAVASSE DC, YAP HH (Eds) 1997: Chemical methods for the control of vectors and pests of public health importance. World Health Organization, $136 \mathrm{p}$.

DUNCAN DB 1955: Multiple range and multiple F-tests. Biometrics 11: 1-42

ELYASSAKI WM 1986: Resistance to pyrethroids in the housefly Musca domestica L. (Diptera Muscidae). Summary of Master of Science Thesis, USA http://www.clyassaki.4t.com/mscsum.html (accessed 18. 2. 2004)

FARNHAM AW 1998: The mode of action of piperonyl butoxide with reference to studying pesticide resistance. In: JONES DG (Ed.): Piperonyl Butoxide: the insecticide synergist. Academic Press, London, pp. 199-214

FINNEY DJ 1977: Probit Analysis. $3^{\text {rd }}$ ed. Cambridge University Press, Cambridge, 328 p.

HODGSON E, LEVI PE 1998: Interactions of piperonyl butoxide with cytochrome P450. In: JONES DG (Ed.): Piperonyl Butoxide: the insecticide synergist. Academic Press, London, pp. 41-53

KASAI S, SCOTT JG 2000: Overexpression of cytochrome P450 CYP6D1 is associated with monooxygenasemediated pyrethroid resistance in house flies from Georgia. Pest Biochem Physiol 68: 34-41

KAYA S, BILGILI A 2002: Ectoparasiter drugs. In: KAYA S, PIRINCCI I, UNSAL A, KARAER Z, TRAS B, BILGILI A, AKAR F, DOGAN A (Eds.): Pharmacology in Veterinary Medicine, Vol 2, $3^{\text {rd }}$ Edition, Medisan, Ankara, pp. 511-603

KEANE P 1998: The use of piperonyl butoxide in formulations for the control of pests of humans, domestic and food animals. In: JONES DG (Ed.): Piperonyl Butoxide: the insecticide synergist. Academic Press, London, pp. 289-300

KOĆIŠOVÁ A, NOVÁK P, TOPORČÁK J, PETROVSKÝ M 2002: Development of resistance in field housefly (Musca domestica): comparison of effects classic spray regimes versus integrated control methods. Acta Vet Brno 71: 401-405

KOCAK O 1998: Pest Control. Technology Application and Research Centre of Hacettepe University, Insecticide Test and Production Unit, Ankara, pp. 3-13

KRISTENSEN M, KNORR M, SPENCER AG, JESPERSEN JB 2000: Selection and reversion of azamethiphosresistance in a field population of the housefly Musca domestica (Diptera: Muscidae), and the underlying biochemical mechanisms. J Econ Entomol 93: 1788-1795

MALLIS A 1969: Handbook of Pest Control. Mac Nair-Dorland Co., New York, 1158 p.

OZDAMAR K 1999: Statistical Data Analysis with Packaged Software. Kaan Kitabevi, Eskişehir, 502 p.

PAP L, ÁRVAI G, BERTÓK B, RIBAI ZK, BAKONYVARI I 2001: Comparative evaluation of new synergists containing a butynyl-type synergophore group and piperonyl butoxide derivates. Pest Manag Sci 57: 186-190

SHOWYIN L 1998: The use of piperonyl butoxide in household formulations. In: JONES DG (Ed.): Piperonyl Butoxide: the insecticide synergist. Academic Press, London, pp. 283-287 
STEWART D 1998: The evaluation of synergistic action in the laboratory and field. In: JONES DG (Ed.): Piperonyl Butoxide: the insecticide synergist. Academic Press, London, pp. 173-198

TEZOK OF, KILICTURGAY K, TOPPARE S, ERSOZ N 1973: Resistance Tests Which Are Performed with Insecticides on Houseflies. Mikrobiyoloji Bülteni, 7: 246-263

TOMLIN CDS (Ed.) 1997: The Pesticide Manual, 11 ${ }^{\text {nd }}$ ed. British Crop. Protection Council, Farnham, 1606 p.

TOZZI A 1998: A brief history of the development of piperonyl butoxide as an insecticide synergist. In: JONES DG (Ed.): Piperonyl Butoxide: the insecticide synergist. Academic Press, London, pp. 1-6

WHO 1981a: Criteria and meaning of tests for determining the susceptibility or resistance of insects to insecticidesdiagnostic test. World Health Organization, Geneva, WHO/VBC/81.6., 4 p.

WHO 1981b: Instructions for determining the susceptibility or resistance of adult mosquitoes to organochlorine, organophosphate and carbamate insecticides-diagnostic test. World Health Organization, Geneva, WHO/ VBC/81.806., 6 p.

WHO 1985: Specifications for pesticides used in public health. World Health Organization, Geneva, p. 384

WHO 1986: Vector control series. The housefly, training and information guide, intermediate level. World Health Organization, Geneva, WHO/VBC/90.987

WHO 1988: Technical report series 767: urban vector and pest control. World Health Organization, Geneva, pp. 1-77

WHO 1990: Environmental health criteria 98: tetramethrin. World Health Organization, Geneva, pp. 1-69

WHO 1992: Technical report series 818: vector resistance to pesticides. World Health Organization, Geneva, $63 \mathrm{p}$.

WICKHAM J 1998: The use of synergized pyrethroids to control insect pests in and around domestic, industrial and food-handling premises. In: JONES DG (Ed.): Piperonyl Butoxide: the insecticide synergist. Academic Press, London, pp. 239-260

YALCIN BC 1975: Statistical Elimination of Some Environmental Factors on Performance Properties. İstanbul Üniversitesi Veteriner Fakültesi Dergisi, 1: 82-102 